\title{
PELATIHAN MANAJEMEN KEUANGAN KELUARGA BAGI ANGGOTA AISYIYAH BANJARMASIN 9 KOTA BANJARMASIN
}

\author{
Lea Emilia Farida ${ }^{1}$, Nailiya Nikmah ${ }^{2}$, Rusman Irwansyah ${ }^{3}$, Sari Hepy Maharani ${ }^{4}$ \\ Jurusan Akuntansi, Politeknik Negeri Banjarmasin ${ }^{123}$ \\ Administrasi Bisnis, Politeknik Negeri Banjarmasin ${ }^{4}$ \\ leaemilia@akuntansipoliban.ac.id ${ }^{1}$ \\ nailiya.nikmah@akuntansipoliban.ac.id ${ }^{2}$ \\ rusman.irwansyah@akuntansipoliban.ac.id ${ }^{3}$ \\ $\underline{\text { sarihepymaharani@poliban.ac.id }}^{4}$
}

\begin{abstract}
The diverse needs of life need to be in the management of family finances, because there can be expenditure more than the amount of income. Lifestyle changes can be a trigger for increased family spending. The purchase of unneeded secondary items can also increase the amount of expenditure. Similarly, the acquisition of consumptive assets or productive asset through an increase in the amount of debt requires the calculation of the portion of debt in accordance with the income. In addition, unexpected events in the family such as the presence of sick family members or payment transactions of children's education funds requiring substantial funds require good management by mothers as household finance managers.The purpose of this community service is to provide training on the management of family finances to Aisyiyah members of Banjarmasin 9 Banjarmasin city.

The benefit of this activity for the partner's devotion is to provide knowledge on how to plan the expenditure of family finances, implementation of family financial management and assessment/ supervision of family finances.
\end{abstract}

Keywords: Familiy financial management, training, Aisyiyah Banjarmasin 9 Banjarmasin City

\begin{abstract}
ABSTRAK
Kebutuhan hidup yang beragam memerlukan kecermatan dalam memanajemen keuangan keluarga, karena bisa saja terjadi pengeluaran melebihi jumlah penghasilan. Perubahan gaya hidup dapat menjadi pemicu peningkatan pengeluaran keluarga. Pembelian barang-barang sekunder yang tidak dibutuhkan juga dapat meningkatkan jumlah pengeluaran. Demikian pula, perolehan aset konsumtif ataupun asset produktif melalui peningkatan jumlah hutang memerlukan perhitungan porsi hutang yang sesuai dengan penghasilan yang dimiliki. Selain itu, peristiwa tak terduga dalam keluarga seperti adanya anggota keluarga yang sakit atau transaksi pembayaran dana pendidikan anak yang memerlukan dana yang cukup besar memerlukan pengelolaan yang baik oleh para ibu sebagai manajer keuangan rumah tangga. Tujuan kegiatan pengabdian kepada masyarakat ini adalah untuk memberikan pelatihan tentang manajemen keuangan keluarga kepada anggota Aisyiyah Banjarmasin 9 Kota Banjarmasin.
\end{abstract}


Manfaat dari kegiatan ini bagi mitra pengabdian adalah memberikan pengetahuan tentang cara merencanakan pengeluaran keuangan keluarga, pelaksanaan manajemen keuangan keluarga dan penilaian/ pengawasan keuangan keluarga.

Kata Kunci: Manajemen Keuangan Keluarga, Pelatihan, Aisyiyah Banjarmasin 9 Kota Banjarmasin

\section{PENDAHULUAN}

Penghasilan yang dimiliki oleh setiap keluarga berasal dari berbagai sumber. Penghasilan ini digunakan untuk memenuhi kebutuhan hidup seharihari. Kebutuhan paling dasar dari hirarki kebutuhan Maslowa adalah kebutuhan fisiologis, yaitu kebutuhan yang berhubungan dengan kebutuhan fisik, seperti kebutuhan makan, minum, tempat berteduh, tidur dan oksigen. Untuk masyarakat yang memiliki penghasilan yang sudah mapan, rasa lapar menjadi gaya hidup karena mereka mencari citarasa dari makanan yang mereka inginkan. Setelah kebutuhan fisiologis terpenuhi, kebutuhan rasa aman menjadi kebutuhan berikutnya. Orang-orang akan berusaha untuk mencari kestabilan dalam keamanan dengan menghindari keadaan yang tidak diharapkan. Adanya penghasilan yang mencukupi memungkinkan seseorang/ keluarga untuk memilih lingkungan tempat tinggal yang aman dan higienis, juga memiliki jaminan asuransi untuk diri dan asetnya.

Kebutuhan berikutnya yang penting untuk dipenuhi setelah kebutuhan fisiologis dan kebutuhan rasa aman terpenuhi adalah kebutuhan akan rasa memiliki dan kasih sayang. Kebutuhan ini berhubungan dengan kebutuhan sosial yang akan menciptkan persahabatan dan keluarga. Penghasilan yang mapan dan maraknya café-café akan mendorong seseorang untuk berkumpul bersama keluarga dan sahabat di cafe-café tersebut. Kebutuhan akan penghargaan menjadi kebutuhan berikutnya setelah kebutuhan kasih sayang terpenuhi. Kebutuhan akan penghargaan dalam tingkatan yang rendah seperti kebutuhan untuk menghormati orang lain, kebutuhan status, ketenaran, dan reputasi, sedangkan kebutuhan akan penghargaan dalam tingkatan yang tinggi adalah kebutuhan harga diri, seperti kompetensi, prestasi, penguasaan, kemandirian dan kebebasan. Pencapaian kedudukan yang lebih tinggi dalam tingkatan pekerjaan sejalan dengan peningkatan penghasilan dapat memicu perubahan gaya hidup dan peningkatan pengeluaran untuk membeli produk/ jasa yang serupa tetapi dengan kualitas yang lebih baik dan harga yang lebih tinggi.

Oleh karena itu, penghasilan yang dimiliki harus dikelola dengan baik, apalagi untuk sebuah keluarga dimana peran pengelolaan keuangan keluarga yang cermat menjadi amanah bagi seorang ibu agar pengeluaran keluarga sesuai dengan penghasilan yang diperoleh, sehingga seluruh kebutuhan penting dalam keluarga dapat terpenuhi secara seimbang untuk mewujudkan keluarga yang bahagia dan sejahtera. Keterampilan untuk mengelola keuangan keluarga dengan bijak merupakan hal utama dan penting dimiliki oleh seorang ibu sebagai manajer keuangan keluarga. 
Kegiatan Pengabdian Kepada Masyarakat Politeknik Negeri Banjarmasin (Poliban) tahun 2019 dalam bentuk pelatihan tentang manajemen keuangan keluarga kepada ibu-ibu anggota Aisyiyah Banjarmasin 9 Kota Banjarmasin sebagai mitra pengabdian. Target kegiatan ini adalah menghasilkan jasa yang bisa diadopsi oleh ibu-ibu tersebut berupa ilmu pengetahuan tentang cara memanajemen keuangan keluarga, yang meliputi ilmu pengetahuan tentang perencanaan pengeluaran keuangan keluarga, ilmu pengetahuan tentang pelaksanaan manajemen keuangan keluarga, dan ilmu pengetahuan tentang penilaian/ pengawasan keuangan keluarga.

Berbagai gerakan bernuansa membangun dari rumah sudah banyak dicanangkan di Indonesia, seperti Indonesian strong from home oleh Ayah Edi, "Gerakan 18.21" oleh Abah Ikhsan. Ayah Edi dan Abah Ikhsan adalah para tokoh parenting di Indonesia. Pelatihan pengelolaan keuangan keluarga sebagai upaya peningkatan keterampilan pengelolaan keuangan keluarga oleh para ibu (istri) pernah dilakukan oleh Evi Marlina dkk (2017) yang dimuat dalam Jurnal Pengabdian Untukmu Negeri serta pengabdian masyarakat yang dilakukan oleh Regina Detty dan Istiharini (2013), Fakultas Ekonomi, Universitas Katolik Parahyangan Bandung. Pelatihan pengelolaan keuangan keluarga bagi kelompok yasinan ibu-ibu komplek Rahayu Jalan Pramuka Banjarmasin juga pernah dilakukan oleh Nailiya Nikmah dkk pada tahun 2018.

Tujuan kegiatan pengabdian kepada masyarakat ini adalah untuk memberikan pelatihan tentang manajemen keuangan keluarga kepada ibuibu Anggota Aisyiyah Banjarmasin 9 Kota Banjarmasin. Manfaat dari kegiatan ini bagi mitra pengabdian adalah memberikan pengetahuan tentang cara merencanakan pengeluaran keuangan keluarga, pelaksanaan manajemen keuangan keluarga dan penilaian/ pengawasan keuangan keluarga. Selain itu, kegiatan ini juga bermanfaat untuk mahasiswa untuk pengembangan softskills mahasiswa tentang kerjasama tim, komunikasi, kreativitas, problem-solving, collaboration, inisiatif, adaptasi, koordinasi dengan orang lain, negosiasi, service orientation dan kepedulian sosial.

\section{METODE KEGIATAN / SOLUSI / TEKNOLOGI}

Adapun tahapan-tahapan pelaksanaan kegiatan pengabdian kepada masyarakat ini, terdiri dari :

1. Membuat proposal pengabdian kepada masyarakat, kemudian dikumpulkan ke P3M Poliban dan di-upload di SIPMA.

2. Melakukan survey dan kunjungan awal pada tanggal 18 Juni 2019 ke mitra pengabdian di dalam kota Banjarmasin dalam rangka kegiatan tersebut yaitu menemui Ibu Dra. Hj. Wilda Hayati selaku Pimpinan Aisyiyah Banjarmasin 9 Kota Banjarmasin di Jalan Pramuka Komplek Rahayu Pembina 4 Perum Griya Rahayu Permai Blok A No 9 Banjarmasin. Tim pelaksana menyampaikan proposal kegiatan dan menjelaskan tentang maksud dan tujuan kegiatan pengabdian kepada masyarakat. 
3. Setelah mendapatkan persetujuan dari pihak Pimpinan Aisyiyah Banjarmasin 9 Kota Banjarmasin dengan menandatangani surat persetujuan mitra kemudian disepakati waktu, tempat dan peserta kegiatan,yaitu pada hari Selasa, 27 Agustus 2019 jam 14.00 - 16.00 wita, bertempat di Jalan Mangga 3 Kelurahan Kebun Bunga Kecamatan Banjarmasin Timur Kota Banjarmasin, dengan peserta ibu-ibu Anggota Aisyiyah Banjarmasin 9 Kota Banjarmasin.

4. Menyiapkan peralatan dan perlengkapan yang dibutuhkan dalam rangka kegiatan kepada masyarakat berupa materi, seminar kit, backdrop, LCD, daftar hadir peserta, undangan, surat persetujuan mitra, berita acara telah melaksanakan pengabdian, dan sertifikat untuk peserta, pembicara dan panitia.

5. Pelaksanaan kegiatan pengabdian kepada masyarakat. menggunakan metode pelatihan tentang manajemen keuangan keluarga yang disertai dengan pemberian contoh bagaimana cara merencanakan pengeluaran keuangan keluarga, pelaksanaan manajemen keuangan keluarga dan penilaian/ pengawasan keuangan keluarga. Adapun yang menjadi nara sumber pada kegiatan ini adalah Ibu Hj. Nurul Mukhlisah, SE, MM dengan kepakaran di bidang akuntansi, keuangan dan manajemen keuangan. Peserta kegiatan kemudian diberikan kesempatan untuk mendiskusikan permasalahan yang berkaitan dengan manajemen keuangan keluarga. Dalam pelaksanaan kegiatan, Panitia pelaksana dibantu oleh 3 orang mahasiswa yang berasal dari Jurusan Akuntansi Poliban yaitu Ahmad Nazlinur Akbar (NIM. D010316031), Evana Yulia Listi Dilsnof (NIM. D010316037) dan Wahyudi (NIM. D010316056), dan 4 orang mahasiswa dari Jurusan Administrasi Bisnis Poliban yaitu Etisa Eldawati (NIM. E010317009), Mahrifah (NIM. E010317018), Untung Slamet Raharjo (NIM. E010317027), dan Khairuddin (NIM. E010317045). Mahasiswa membantu dalam persiapan konsumsi (snack dan makan siang) untuk peserta, pengisian daftar hadir, menyiapkan LCD, memasang backdrop, menjadi pembawa acara, dan mendokumentasikan kegiatan dalam bentuk foto dan video.

6. Penyusunan laporan kegiatan pengabdian kepada masyarakat berdasarkan Pedoman Pelaksanaan Penelitian dan Pengabdian Kepada Masyarakat Poliban Tahun 2018.

7. Publikasi artikel ke jurnal pengabdian kepada masyarakat Poliban (Jurnal IMPACT) yang bias diaksese melalui website ejurnalpoliban.ac.id dan melalui publikasi video singkat pengabdian kepada masyarakat yang diupload ke youtube (https://youtu.be/ID-NKH9iNwY).

8. Hasil yang dicapai dari kegiatan ini berupa jasa yang bisa diadopsi oleh masyarakat berupa ilmu pengetahuan tentang cara memanajemen keuangan keluarga, yang meliputi ilmu pengetahuan tentang perencanaan pengeluaran keuangan keluarga, ilmu pengetahuan tentang pelaksanaan manajemen keuangan keluarga, dan ilmu pengetahuan tentang penilaian/ pengawasan keuangan keluarga. Target lainnya adalah berupa adanya integrasi pengabdian dalam pembelajaran berupa bab dalam bahan ajar dalam mata kuliah Manajemen Keuangan tentang manajemen keuangan keluarga. 
9. Penyerahan laporan pengabdian kepada masyarakat kepada Pusat Penelitian dan Pengabdian Kepada Masyarakat (P3M) Poliban.

\section{HASIL DAN PEMBAHASAN}

Hasil yang dicapai dari kegiatan ini berupa jasa yang bisa diadopsi oleh masyarakat berupa ilmu pengetahuan tentang cara memanajemen keuangan keluarga, yang meliputi ilmu pengetahuan tentang perencanaan pengeluaran keuangan keluarga, ilmu pengetahuan tentang pelaksanaan manajemen keuangan keluarga, dan ilmu pengetahuan tentang penilaian/ pengawasan keuangan keluarga. Target lainnya adalah berupa adanya integrasi pengabdian dalam pembelajaran berupa bab dalam bahan ajar dalam mata kuliah Manajemen Keuangan tentang manajemen keuangan keluarga.

Adapun luaran dari kegiatan ini adalah berupa artikel yang dipublikasikan di jurnal IMPACT yaitu jurnal pengabdian kepada masyarakat Poliban (ejurnalpoliban.ac.id) dan melalui publikasi video singkat pengabdian kepada masyarakat yang diupload ke youtube (https://youtu.be/ID-NKH9iNwY).

\section{KESIMPULAN}

Pelaksanaan kegiatan pengabdian kepada masyarakat berupa pelatihan tentang manajemen keuangan keluarga yang disertai dengan pemberian contoh bagaimana cara merencanakan pengeluaran keuangan keluarga, pelaksanaan manajemen keuangan keluarga dan penilaian/ pengawasan keuangan keluarga, dengan mitra kerjasama pengabdian adalah ibu-ibu Aisyiyah Banjarmasin 9 Kota Banjarmasin. Sebaiknya dilakukan penelitian terkait dengan pengelolaan keuangan keluarga untuk mengetahui sejauhmana pemahaman para ibu sebagai manajer keuangan keluarga dapat menerapkan pengelolaan keuangan keluarga yang bijak.

\section{UCAPAN TERIMA KASIH}

Tim Pelaksana mengucapkan terimakasih kepada Pimpinan Aisyiyah Banjarmasin 9 Kota Banjarmasin yang telah bersedia menjadi mitra kerjasama kegiatan pengabdian kepada masyarakat Poliban. Ucapan terima kasih juga disampaikan kepada Kepala P3M Poliban yang telah memfasilitasi kegiatan dan pendanaan pengabdian sehingga kegiatan ini dapat terselenggara dengan lancar.

\section{DAFTAR PUSTAKA}

Detty, Regina., dan Istiharini, 2013. Pengelolaan Keuangan Keluarga yang Efektif bagi Para Ibu Rumah Tangga di Daerah Dayeuh Kolot dan Manggahang, Kabupaten Bandung, Fakultas Ekonomi, Universitas Katolik Parahyangan Bandung. (Journal.unpar.ac.id/index.php/sosial/ article/view/208/193). 
Marlina, Evi., dkk, 2017, Perwujudan Keluarga Sakinah Melalui Pengelolaan Keuangan Rumah Tangga Secara Islami, Jurnal Pengabdian untukmu Negeri Vol.1, No.2, November 2017. ISSN: 2550-0198.

Puspitawati, Herien., 2013, Konsep dan Teori Keluarga, Fakultas Ekologi Manusia - Institut Pertanian Bogor.

Suhartini, Dwi., dan Jefta, Ardhian, Renanta., Pengelolaan Keuangan Keluarga Pedagang Etnis Cina, Jurnal Riset Ekonomi dan Bisnis Vol. 7 No. 2 September 2007. E-mail : dwie_upn12@yahoo.co.id.

Nikmah, Nailiya., dkk, 2018, Pelatihan pengelolaan keuangan keluarga bagi kelompok yasinan ibu-ibu komplek Rahayu Jalan Pramuka Banjarmasin, Jurnal IMPACT Vol. 1 No. 2 hal 131-137. 